Mini Review

\section{The airborne dilemma}

\section{Stephen Z Fadem*}

MD, FASN, Clinical Professor of Medicine, Medicine-Nephrology, Baylor College of Medicine, Houston Texas, USA
Received: 10 October, 2020

Accepted: 05 April, 2021

Published: 06 April, 2021

*Corresponding author: Stephen Z Fadem, MD, FASN, Clinical Professor of Medicine, Medicine-Nephrology, Baylor College of Medicine, Houston, Texas, USA, E-mail: fadem@bcm.edu

https://www.peertechzpublications.com

\section{Introduction}

In December 2019, there were 44 cases of an atypical pneumonia found to be related to a novel coronavirus, SARS$\mathrm{CoV}-2$. The disease was classified as a global health emergency one month later and reached pandemic proportion by March 11,2020 . By October 2020, it had killed over 1,000,000 people. By April 2021, there were nearly 3 million deaths. Not only has this virus been costly in terms of life but has had lasting side effects. It has been difficult to contain, sometimes resulting in overloading of hospital critical care services and disruption of regular care. It has also devastated the economy, particularly sectors related to tourism and transportation. Even the Summer Olympics were postponed. We have had severe pandemics throughout our history, but the last one this devastating was the Spanish Influenza of 1918. The world was unprepared for this onslaught.

The Sars-CoV-2 virus is highly transmissible, covered with spiked proteins with ligand tips that specifically attack the Angiotensin-Converting Enzyme 2 (ACE2) receptor of the upper airways and lungs, particularly type 2 alveolar cells. A serine protease cleaves the spiked protein enabling cellular entry. The virus enters the cell through endocytosis where a lysosomal protease disrupts the virus, releasing RNA. Inside the cell, RNA replicates itself and also produces the nucleocapsid. The capsid and gene are reassembled to make a new virus that is released from the cell $[1,2]$.

Some patients with COVID-19 develop an Adult Respiratory Distress Syndrome (ARDS). This is associated with high rates of cytokine production. Of those who have higher levels of C-reactive protein, higher neutrophil, lower lymphocyte, and elevated Interleukin- 6 levels, $62 \%$ require assisted ventilation and have worse outcomes [3].

The lethal and novel viral pathogen is highly infective. It was surprising and devastating that the disease could spread in asymptomatic patients. In a screen of 2,454 articles from seven countries, testing 21,708 persons who were at risk, 111 of 663 positive patients were asymptomatic with a range from $4-41 \%$ (proportion $17 \%, 95 \% \mathrm{CI} 14-20 \%$ ). What is puzzling is that the relative risk of transmission is only $42 \%$ lower in patients without symptoms (RR 0.58; 95\%CI 0.335-0.994, $\mathrm{p}=0.047$ ) [4]. A disease that is lethal but often spreads without symptoms is discomforting to any community. One can assume a patient who is coughing and sneezing will be an obvious source of infection, but the question is how the disease spreads when one is asymptomatic. Asymptomatic persons are not coughing. It has been established with influenza that viral pathogens can be transmitted by breathing or speaking [5]. It is concerning that this is also true with the SARS-CoV-2 virus.

\section{Is the virus also airborne?}

Particles can be divided into droplets $>5 \mu \mathrm{m}$, and aerosols $<5 \mu \mathrm{m}$. Respiratory infections can carry droplet particles greater than $5 \mu \mathrm{m}$ through coughing and sneezing. These larger particles are heavier and expected to drop onto a surface within 6 feet and not linger in the air. They can also be directed to the face or air passages of a nearby person. This the logic behind maintaining a social distancing at least 6 feet, but this only holds true when particles are large.

If an infection is airborne, then one assumes the infected particles are carried in aerosols under $5 \mu \mathrm{m}$. The airborne particles can linger in the air for hours and can be moved by air currents such as via the air conditioner. Respiratory droplets produced during exhalation (e.g., breathing or speaking) are capable of emitting aerosols containing the influenza virus at as many as 10 particles per second. Mathematically, this amounts to 600 particles per minute, or 6,000 particles in a 10 -minute conversation. Speaking loudly can introduce even more aerosol particles into the air [6]. It is suggested that SARS-CoV-2 might behave similarly. Viral emission from talking, breathing, or even singing can be aerosolized. Hence, the disease is considered airborne and is highly contagious. 
The literature regarding the collection of air samples from negative pressure medical rooms accommodating confirmed COVID-19 patients has been mixed. Although copies of the virus were identified, they have yet to be cultured. Yet, spread by aerosol is of concern, particularly in poorly contaminated indoor areas. After a $2.5 \mathrm{hr}$ choir practice, 33 out of 61 choir members of the Skagit Valley Chorale died, despite refraining from hugs or handshakes and using hand sanitizer [7]. It makes sense that this group had a worse course and might suggest that disease spread via aerosol is contained in smaller particles. While particles in the 6-12 $\mu \mathrm{m}$ range may deposit in the upper airways, small particles under $5 \mu \mathrm{m}$ can deposit in the lower respiratory tracts and could lead to pneumonia. Aerosols can travel up to 7-8 $\mathrm{m}$ while the larger droplet particles fall to the ground within $2 \mathrm{~m}$ [8]. Air conditioner ventilation can also transmit the virus, as was shown using tracer gas to study aerosol transmission after a Chinese New Year outbreak in a restaurant on January 24,2020 , in Guangzhou, China, which affected 10 persons dining at three tables of non-associated families. On a bus in Hunan province, 8 of 49 persons became infected, even though social distancing protocols were followed, including entering and exiting the bus through a separate door.

There is a difference between the virus and the particles that might contain the virus, although this might be easily confused. A person who is exhaling respiratory particles but not wearing a mask may spread these particles to persons nearby regardless of particle size. The person wearing a mask will filter particles; if these particles contain the virus, they too will be filtered. The KF94 and N95 masks effectively capture viral particles. Surgical masks are less effective that N95 at capturing particles [9]. The logic behind the mask is that the particles will be contained in the wearer's mask whether speaking or coughing regardless of whether it contains the viral pathogen, minimizing the risk of contaminating someone else or a surface.

The chance of inhaling a virus depends on the number of viral pathogens surrounding one's nose and mouth. When the viral load is high, a mask may be of limited value in protecting the wearer, but is more effective when the abundance of the virus is low, especially if it is lower than the number of viral particles needed to cause a respiratory infection. Wearing a mask does not necessarily protect the wearer from acquiring the disease [10], particularly if the virus is airborne.

\section{Should we continue wearing masks after being vaccina- ted?}

Millions of persons around the world have received vaccines to protect against COVID-19. Does that mean we no longer need to wear masks?

1. The answer lies in how the new variant mutations will make the virus more or less virulent, as the virus is under pressure to mutate into newer strains that can evade the vaccination's stimulus to create neutralizing antibodies. Variants that evade the benefit of vaccination will force our reliance on masks and social distancing.
Masks mostly protect those persons surrounding the wearer, but not necessarily the wearer. It has been established that dialysis patients are the most vulnerable to develop serious outcomes and thus require a hospitalization when they acquire COVID-19 [11]. Preliminary studies demonstrated that after a single dose messenger RNA vaccine, organ transplantation recipients only developed neutralizing antibodies at a rate of $17 \%$; (CI, $14 \%$ to $21 \%)$ [12].

Preliminary studies are demonstrating that the viral load for infections is reduced fourfold within the first month of the first dose of the BNT162b2 MRNA vaccine. Further research is needed to determine how long any SARS-CoV-2 virus can be harbored in the nasal carriage of asymptomatic persons who have received the vaccine [13].

Add present-day unknowns to the question of whether the disease is airborne, then the message resonates that masks should still be advised, particularly when caring for or socializing with those persons in vulnerable populations. Although the debate continues as to whether SARS-CoV-2 is airborne, persons who are vulnerable are urged to act as though it is indeed airborne and should avoid congregating particularly indoors and in areas where ventilation is poor. Caution is further advised when using public transportation. As our knowledge increases, we may relax our restrictions altogether. But for now, wearing a properly fitting mask and following social distancing protocols are critical, including frequent hand washing/hand sanitizing [14] .

Take home messages:

- The virus can spread through droplets that are large and remain in the air only a few seconds, and travel only six feet.

- There is some evidence that it may be contained in droplets that are smaller, hence airborne.

- Masks may capture the virus in varying degrees, depending upon viral load and the quality of the mask They may not protect the wearer, however.

- Dialysis patients are highly vulnerable.

- Transplantation patients who are immunosuppressed may not respond to the vaccine.

- The vaccine may reduce but not stop transmissibility.

- Viral variants may defeat or evade the vaccine's effort to induce neutralizing antibodies.

- Given the unknowns, it is advisable to continue wearing a mask, social distancing, and minimize congregating until we have further data.

\section{References}

1. Shang J, Wan Y, Luo C, Ye G, Geng Q, et al. (2020) Cell entry mechanisms of SARS-CoV-2. Proc Natl Acad Sci U S A 117: 11727-11734. Link: https://bit.ly/3cM3V02 
2. Naqvi AAT, Fatima K, Mohammad T, Fatima U, Singh IK, et al. (2020) Insights into SARS-CoV-2 genome, structure, evolution, pathogenesis and therapies: Structural genomics approach. Biochim Biophys Acta Mol Basis Dis 1866: 165878. Link: https://bit.ly/3mvABON

3. Quartuccio L, Sonaglia A, McGonagle D, Fabris M, Peghin M, et al. (2020) Profiling COVID-19 pneumonia progressing into the cytokine storm syndrome: results from a single Italian Centre study on tocilizumab versus standard of care. J Clin Virol 129: 104444. Link: https://bit.ly/31LCD3B

4. Byambasuren O, Cardona M, Bell K, Clark J, McLaws ML, et al. (2020) Estimating the extent of asymptomatic COVID-19 and its potential for community transmission: systematic review and meta-analysis. medRxiv 2020. Link: https://bit.ly/3dD5s7E

5. Yan J, Grantham M, Pantelic J, Bueno de Mesquita PJ, Albert B, et al. (2018) Infectious virus in exhaled breath of symptomatic seasonal influenza cases from a college community. Proc Natl Acad Sci U S A 115: 1081-1086. Link: https://bit.ly/39I1Z6Z

6. Asadi S, Bouvier N, Wexler AS, Ristenpart WD (2020) The coronavirus pandemic and aerosols: Does COVID-19 transmit via expiratory particles? Aerosol Sci Technol 54: 635-638. Link: https://bit.ly/3cNyvpW

7. Hamner L, Dubbel P, Capron I (2020) High SARS-CoV-2 Attack Rate Following Exposure at a Choir Practice - Skagit County, Washington, March 2020 MMWR Morb Mortal Wkly Rep 69: 606-610. Link: https://bit.ly/31KNsmi

8. Fennelly KP (2020) Particle sizes of infectious aerosols: implications for infection control. Lancet Respir Med 8: 914-924. Link: https://bit.ly/39F9N9y
9. Kim MC, Bae S, Kim JY, Park SY, Lim JS, et al. (2020) Effectiveness of surgical, KF94, and N95 respirator masks in blocking SARS-CoV-2: a controlled comparison in 7 patients. Infect Dis (Lond) 52: 908-912. Link: https://bit.ly/3wrfOA9

10. Bundgaard $\mathrm{H}$, Bundgaard JS, Raaschou-Pedersen DET, von Buchwald $\mathrm{C}$ Todsen T, et al. (2021) Effectiveness of Adding a Mask Recommendation to Other Public Health Measures to Prevent SARS-CoV-2 Infection in Danish Mask Wearers: A Randomized Controlled Trial. Ann Intern Med 174: 335-343. Link: https://bit.ly/20kku9R

11. Oetjens MT, Luo JZ, Chang A, Leader JB, Hartzel DN, et al. (2020) Electronic health record analysis identifies kidney disease as the leading risk factor for hospitalization in confirmed COVID-19 patients. PLoS One 15: e0242182. Link: https://bit.ly/3cOY7CY

12. Boyarsky BJ, Werbel WA, Avery RK, Tobian AAR, Massie AB, et al. (2021) Immunogenicity of a Single Dose of SARS-CoV-2 Messenger RNA Vaccine in Solid Organ Transplant Recipients. JAMA 15: e214385. Link: https://bit.ly/3fE53ok

13. Levine-Tiefenbrun M, Yelin I, Katz R, Herzel E, Golan Z, et al. (2021) Decreased SARS-CoV-2 viral load following vaccination. medRxiv 2021. Link: https://bit.ly/3wlt6hE

14. Lewis D (2020) Mounting evidence suggests coronavirus is airborne - but health advice has not caught up. Nature 583: 510-513. Link: https://bit.ly/3cOfIL7

\section{Discover a bigger Impact and Visibility of your article publication with} Peertechz Publications

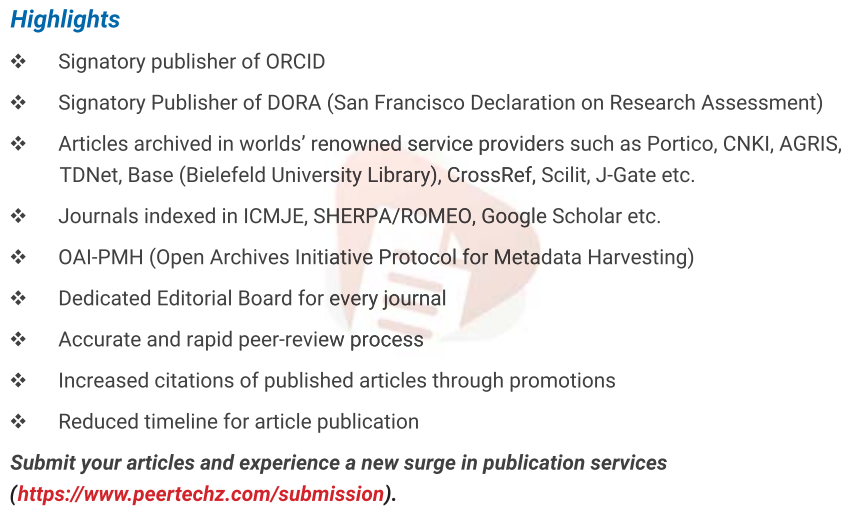

Peertechz journals wishes everlasting success in your every endeavours.

Copyright: ㄷ 2021 Fadem SZ. This is an open-access article distributed under the terms of the Creative Commons Attribution License, which permits unrestricted use distribution, and reproduction in any medium, provided the original author and source are credited. 